Article

\title{
Bone Marrow Protein Oxidation in Response to Ionizing Radiation in C57BL/6J Mice
}

\author{
Yong-Chul Kim ${ }^{1}$, Michal Barshishat-Kupper ${ }^{1}$, Elizabeth A. McCart ${ }^{1}$, Gregory P. Mueller ${ }^{2}$ \\ and Regina M. Day ${ }^{1, *}$
}

1 Department of Pharmacology, Uniformed Services University of the Health Sciences, Bethesda, MD 20814, USA; E-Mails: yongchul.kim.ctr@usuhs.edu (Y.-C.K.); michalkupper@gmail.com (M.B.-K.); elizabeth.mccart@usuhs.edu (E.A.M.)

2 Department of Anatomy, Physiology and Genetics, Uniformed Services University of the Health Sciences, Bethesda, MD 20814, USA; E-Mail: gregory.mueller@usuhs.edu

* Author to whom correspondence should be addressed; E-Mail: regina.day@usuhs.edu; Tel.: +1-301-295-3236; Fax: +1-301-295-3220.

Received: 18 April 2014; in revised form: 5 June 2014 / Accepted: 10 June 2014 /

Published: 25 June 2014

\begin{abstract}
The bone marrow is one of the most radio-sensitive tissues. Accidental ionizing radiation exposure can damage mature blood cells and hematopoietic progenitor/stem cells, and mortality can result from hematopoietic insufficiency and infection. Ionizing radiation induces alterations in gene and protein expression in hematopoietic tissue. Here we investigated radiation effects on protein carbonylation, a primary marker for protein oxidative damage. C57BL/6 mice were either sham irradiated or exposed to $7.5 \mathrm{~Gy}{ }^{60} \mathrm{Co}$ $(0.6 \mathrm{~Gy} / \mathrm{min})$ total body irradiation. Bone marrow was obtained $24 \mathrm{~h}$ post-irradiation. Two dimensional (2-D) gel electrophoresis and Oxyblot immunodetection were used to discover carbonylated proteins, and peptide mass fingerprinting was performed for identification. 2D gels allowed the detection of 13 carbonylated proteins in the bone marrow; seven of these were identified, with two pairs of the same protein. Baseline levels of carbonylation were found in $78 \mathrm{kDa}$ glucose-related protein, heat shock protein cognate $71 \mathrm{KDa}$, actin, chitinase-like protein 3 (CHI3L1), and carbonic anhydrase 2 (CAII). Radiation increased carbonylation in four proteins, including CHI3L1 and CAII, and induced carbonylation of one additional protein (not identified). Our findings indicate that the profile of specific protein carbonylation in bone marrow is substantially altered by ionizing radiation.
\end{abstract} Accordingly, protein oxidation may be a mechanism for reduced cell viability. 
Keywords: acute radiation syndrome; protein carbonylation; proteomic analysis

\section{Introduction}

High dose total body irradiation may occur as the result of a nuclear accident or terrorist event. Radiotherapy is also a common therapeutic modality for cancer treatment, including for leukemia and lymphoma. Unfortunately, radiation therapy is not tumor-specific and underlying normal tissues, particularly the bone marrow, are extremely vulnerable to radiation injury. The acute hematopoietic effects of total body exposure to ionizing radiation in humans, termed Hematopoietic Syndrome, usually occur within $\sim 30-60$ days following exposures greater than 2 Gy. In the extreme, this condition results in death from hematopoietic insufficiency and infection [1].

Ionizing radiation destroys both mature blood cells and hematopoietic progenitor/stem cells in the bone marrow compartment, reducing the number of resident, tissue-specific adult stem cells that are critical for hematopoietic repair and regeneration. While loss of mature blood cells is a key factor in radiation morbidity, mortality is believed to occur due to prolonged myelosuppression from the loss of hematopoietic progenitor cells (HPC) and primitive hematopoietic stem cells (HSC) [2,3]. A delicate balance between HSC self-renewal, proliferation, and differentiation is required to ensure proper bone marrow HSC repopulation, progenitor cell reconstitution, and mature blood cell production [4]. Normally, HSC quiescence ensures life-long maintenance of the HSC pool, protecting against premature exhaustion of hematopoietic potential [5].

Studies have shown that high dose ionizing radiation induces senescence and apoptosis of the HSC resulting in exhaustion of the stem cell pool [6-8]. Work from our laboratory demonstrated that Lin $^{-}$ bone marrow progenitor cells from mice exposed to $7.5 \mathrm{~Gy}$ total body irradiation exhibited decreased expression of genes associated with cellular proliferation and progression of the cell cycle and increased expression of genes associated with cell cycle checkpoints and cell cycle arrest [6]. The expression of key cell cycle regulation and checkpoint genes Ak1, Ccna1, Cdkn1a, Cdkn1b, Cdkn2a, Hus1, Npm2, Prmp1, Pmp22 and Trp63 were increased in response to total body irradiation [6]. Subsequent microarray analyses from other investigators indicated that up to 1302 genes were differentially expressed between 3-21 days postirradiation, affecting multiple biological processes including self-renewal, hematopoiesis, adhesion, differentiation, and immune response [8-10]. Additionally, ATM/CHEK2/p53 and AKT/PI3K signaling pathways were shown to be activated for as long as 4 weeks postirradiation, correlating with prolonged pro-apoptotic signaling following radiation exposure [8,9]. Experiments using qRT-PCR directed toward the detection of specific gene products associated with programmed cell death demonstrated increased expression of Bax and caspase- 9 in total bone marrow cells following radiation exposure [11]. Thus, altered gene expression correlates with the loss of clonogenicity of the bone marrow cells following radiation exposure due to either apoptosis and/or accelerated senescence.

A recent proteomic study compared altered protein expression in the bone marrow of $\mathrm{CBA} / \mathrm{Ca}$ and C57BL/6 strains of mice following 4 Gy radiation exposure [12]. Interestingly, $\mathrm{CBA} / \mathrm{Ca}$ mice are more resistant to radiation-induced hematopoietic cell damage than $\mathrm{C} 57 \mathrm{BL} / 6$ mice, and the protein 
expression patterns were shown to also differ between the two strains of mice [12]. In CBA/Ca mice, 18 proteins had altered expression following radiation exposure, but in C57BL/6 mice 27 proteins were altered after radiation [12]. In both strains of mice, radiation induced the expression of serum albumin, apolipoprotein A-1, $\alpha$-ferroprotein, haptoglobin, and $\alpha$-1-antitrypsin. The proteins serotransferrin, neutrophil collagenase, and peroxiredoxin 2 were altered only in C57BL/6 mice [12]. The classifications of several of these proteins were proposed to be associated with long-term pathological impact of radiation on the bone marrow. For instance, apolipoprotein A-1, $\alpha-1$-antitrypsin, and $\alpha$-ferroprotein were classified as potential markers for acute-phase radiation response, potentially due to altered cytokine regulation following ionizing radiation exposure [12]. Additionally, changes in levels of neutrophil collagenase and $\alpha$-1-antitrypsin were proposed to be related to increased inflammatory responses following radiation exposure [12]. Importantly, the proteomic analysis of the bone marrow tissue following radiation exposure provided a different data set of radiation-induced cellular changes compared with the data set provided by gene expression analyses, providing an increased understanding of the cellular and biological impact of radiation on the bone marrow environment.

Studies have indicated that total body irradiation causes persistent oxidative stress in the hematopoietic compartment [13,14]. Although DNA damage has long been considered the most critical biological effect of ionizing radiation [13], a number of studies have indicated that radiation damage to other biological molecules, including proteins, also has significant impact on cellular viability and clonogenicity [15-17]. Using primary endothelial cell cultures, we previously demonstrated that protein oxidation by radiation can lead to endoplasmic reticulum (ER) stress, that can lead to programmed cell death [17]. Here we have investigated the alterations in protein oxidation induced by radiation in the bone marrow using two dimensional (2-D) gel electrophoresis and Oxyblot detection of protein carbonylation. Peptide mass fingerprinting was then used for the identification of carbonylated proteins. The present findings show that radiation exposure alters the profile of protein carbonylation in bone marrow to produce a biosignature for radiation injury. We propose that the identification of the proteins involved will increase our overall understanding of the biological effects of ionizing radiation.

\section{Experimental}

\subsection{Chemicals}

Except where noted, chemicals were purchased from Sigma-Aldrich (St. Louis, MO, USA).

\subsection{Animals}

C57BL/6J strain female mice (The Jackson Laboratory, Bar Harbor, ME, USA) weighing 17.5-21.5 g were 12-14 weeks of age at the time of irradiation. Mice were kept in a barrier facility for animals accredited by the Association for Assessment and Accreditation of Laboratory Animal Care International. Mice were housed in groups of four. Animal rooms were maintained at $21 \pm 2{ }^{\circ} \mathrm{C}$, $50 \% \pm 10 \%$ humidity, and 12-h light/dark cycle with commercial freely available rodent ration (Harlan Teklad Rodent Diet 8604, Frederick, MD, USA). Acidified water ( $\mathrm{pH}=2.5-3.0)$ was available ad libitum to control opportunistic infections [18]. All animal handling procedures were performed in compliance with guidelines from the National Research Council for the ethical handling of laboratory 
animals, and were approved by the Institutional Animal Care and Use Committee of the Armed Forces Radiobiology Research Institute (AFRRI, Bethesda, MD, USA).

\subsection{Irradiation}

Mice were exposed to a whole body gamma radiation in a bilateral field at AFRRI's ${ }^{60}$ Co facility. The midline tissue dose to the animals was 7.00-7.50 Gy at a dose rate of 0.6 Gy/min. Control animals were sham irradiated. The alanine/electron spin resonance (ESR) dosimetry system (American Society for Testing and Materials, Standard E 1607) was used to measure dose rates (to water) in the cores of acrylic mouse phantoms. To simulate a mouse, the phantoms were 3 inches in length and 1 inch in diameter. For field mapping, all exposure rack compartments contained phantoms, and alternate phantoms contained alanine dosimeters. The ESR signals were measured using a calibration curve based on the standard calibration dosimeters (National Institute of Standards and Technology (NIST), Gaithersburg, MD, USA). The overall uncertainty in the doses given to the calibration dosimeters at NIST was approximately $1.8 \%$ at 2 standard deviations. The accuracy of the calibration curve was verified by parallel measurements of doses to selected dosimeters at AFRRI and the National Physical Laboratory (Middlesex, UK). Corrections were applied to the dose rates in phantoms for the decay of

${ }^{60} \mathrm{Co}$ and differences in the mass energy-absorption coefficients for water and soft tissue.

\subsection{Protein Oxidation Detection by OxyBlot}

Total bone marrow was obtained by flushing the femurs and tibias with phosphate buffered saline (PBS) using a $23 \mathrm{~g}$ needle. Bone marrow proteins were extracted using $1 \mathrm{~mL}$ of the following protein lysis buffer (PLYB): $10 \mathrm{mM} \mathrm{Na}_{4} \mathrm{P}_{2} \mathrm{O}_{7}, 50 \mathrm{mM} \mathrm{NaF}, 50 \mathrm{mM} \mathrm{NaCl}, 1 \mathrm{mM}$ EDTA (pH = 8.0), $50 \mathrm{mM}$ HEPES, $1 \%$ Triton X100, adjusted to $\mathrm{pH}=7.5,2 \mathrm{mM} \mathrm{Na}_{3} \mathrm{VO}_{4}, 1 \mathrm{mM}$ PMSF, $1 \mathrm{mM}$ DTPA and 1 tablet/10 mL buffer of complete mini (Roche Applied Science, Indianapolis, IN, USA) with 1 tablet per $10 \mathrm{~mL}$ buffer of complete protease inhibitors (Roche Applied Science, Indianapolis, IN, USA). The OxyBlot oxidized protein detection kit was purchased from Chemicon (Millipore, Billerica, MA, USA). 2,4-Dinitrophenylhydrazine (DNPH) derivatization was performed for 15 min at room temperature following manufacturer's instruction using $10 \mu \mathrm{g}$ of protein. After DNPH derivatization, proteins were subjected to two-dimensional gel electrophoresis (see below). For immunodetection, proteins were transferred to polyvinylidene difluoride (PVDF) membranes. Membranes were blocked with $1 \%$ BSA in phosphate buffer saline (PBS) containing (w/v) $0.05 \%$ Tween-20 for $1 \mathrm{~h}$ at RT. After overnight $4{ }^{\circ} \mathrm{C}$ incubation with anti-DNP antibody, blots were washed three times and secondary rabbit antibody was added for $1 \mathrm{~h}$ at ambient temperature. Blots were washed and developed using a SuperSignal West Pico chemiluminescence detection system (Thermo Scientific, Rockford, IL, USA). As a negative control, samples were not derivatized with DNP [19]. Densitometry on scanned films used ImageJ software [20].

\subsection{2-D Gel Electrophoresis}

Protein extraction from the bone marrow was performed as described for one-dimensional gels [21]. Four volumes of $10 \mathrm{mM}$ DNPH (in $2 \mathrm{M} \mathrm{HCl}$ ) were added to $200 \mu \mathrm{g}$ protein extract of each sample and 
incubated for $30 \mathrm{~min}$ at room temperature. A final concentration of $15 \%$ of ice cold trichloroacetic acid (TCA) was added to each sample and incubated for $10 \mathrm{~min}$ on ice. Samples were centrifuged for $10 \mathrm{~min}$ at $16,000 \times \mathrm{g}$ at $4{ }^{\circ} \mathrm{C}$. Pellets were washed three times with ethanol ethyl acetate $(1: 1)$ and centrifuged at $16,000 \times g$ for $15 \mathrm{~min}, 4{ }^{\circ} \mathrm{C}$. 2-D gel electrophoresis was performed according to manufacturer's instructions (2-D Starter Kit, Bio-Rad Laboratories, Hercules, CA, USA). Pellets were resuspended in 2-D rehydration buffer. The first dimension separation was performed with the Protean Isoelectric Focusing (IEF) Cell (Bio-Rad Laboratories). Samples were applied to immobilized $\mathrm{pH}$ gradient strips (nonlinear $\mathrm{pH}$ 5-8) for $1 \mathrm{~h}$ at room temperature and then covered with mineral oil and subjected to IEF. Protein IEF strips were reduced and alkylated by incubating for $10 \mathrm{~min}$ each in Equil Buffers 1 and 2 according to the manufacturer's instructions. The strips were embedded in $0.7 \%$ agarose on top of 4\%-20\% acrylamide gels (Criterion precast gels, Bio-Rad Laboratories) and subjected to second dimension electrophoresis. Proteins were transferred to PVDF membranes using a shortened protocol $(20 \mathrm{~min}, 20 \mathrm{~V}$ ) so that proteins remaining in the partially transferred gels could be visualized by Coomassie staining (SimplyBlue Safe Stain, Invitrogen, Carlsbad, CA, USA). Carbonylated proteins detected on the Oxyblot immunoblots were mapped to corresponding features on Commassie stained gels (Bio-Rad). The features were excised for peptide mass finger printing.

\subsection{Peptide Mass Fingerprinting for Protein Identification}

Protein identifications were assigned on the basis of peptide mass fingerprinting performed as described previously [22]. Briefly, protein spots were destained, the gel fragments were then equilibrated with $0.2 \mathrm{~mL}$ of $100 \mathrm{mM} \mathrm{NH} \mathrm{HCO}_{3} / 50 \%$ acetonitrile for $45 \mathrm{~min}$ at $37{ }^{\circ} \mathrm{C}$, dehydrated in $100 \mu \mathrm{L} \mathrm{100 \%}$ acetonitrile and dried under vacuum. The dried gel pieces were rehydrated with $40 \mathrm{mM}$ $\mathrm{NH}_{4} \mathrm{HCO}_{3} / 10 \%$ acetonitrile containing $20 \mathrm{ng} / \mu \mathrm{L}$ trypsin (Trypsin Gold, Mass Spectrometry Grade, Promega, Madison, WI, USA) and incubated overnight at $37{ }^{\circ} \mathrm{C}$. Peptide fragments were recovered in sequential (60 min, room temperature) extractions with $1.0 \%$ trifluoroacetic acid (TFA, $75 \mu \mathrm{L}$ ) followed by two rinses with $50 \%$ acetonitrile/5\% TFA $(50 \mu \mathrm{L}$ each). The three collections were pooled, dried under vacuum and dissolved in $10 \mu \mathrm{L}$ of $1 \%$ TFA. The peptides were then purified and concentrated using a C18 Zip Tip ${ }^{\circledR}$ (Millipore Corporation, Billerica, MA, USA) and mixed with alpha-cyanohydroxycinnamic acid matrix $(10 \mathrm{mg} / \mathrm{mL}$ in $50 \%$ acetonitrile/ $0.1 \%$ TFA) containing bradykinin (1060.5692 daltons; $50 \mathrm{fmol} / \mathrm{mL})$ and adrenocorticotropic hormone fragment 18-39 (2465.1989 daltons; $150 \mathrm{fmol} / \mathrm{mL}$; AnaSpec, San Jose, CA, USA) as internal standards. Samples were analyzed by matrix-assisted laser desorption ionization time-of-flight (MALDI-TOF) mass spectrometry using a Voyager MALDI-TOF DE-STR instrument (PE Biosystems, Framingham, MA, USA). The mass spectrometer was operated in reflectron mode with an accelerating voltage of $20,000 \mathrm{~V}$, a grid voltage of $76.13 \%$ and a guidewire voltage of $0.003 \%$. Peptide mass data were used to query the National Center for Biotechnology Information (NCBI; Bethesda, MD, USA) protein sequence database accessed through the ProteinProspector MS-Fit search engine [23,24]. Protein assignments were made on two criteria: (1) probability scores derived from the Molecular Weight Search (MOWSE) of ProteinProsector, based upon mass matches and percent protein sequence coverage, and (2) minimal frequency of three observations across four separate experiments. Published evidence supporting the assignments was also taken into account. 


\section{Results and Discussion}

\subsection{Radiation-Induced Protein Carbonylation in Bone Marrow Tissue}

The present investigation revealed that ionizing radiation substantially alters the pattern of protein carbonylation in bone marrow, suggesting a causative mechanism for radiation-induced disruptions in hematopoiesis. We previously demonstrated that the median lethal dose at 30 days $\left(\mathrm{LD}_{50 / 30}\right)$ with $95 \%$ confidence limits for female C57BL/6J mice was $7.52 \mathrm{~Gy}(7.44 \mathrm{~Gy}, 7.59 \mathrm{~Gy})$ in the AFRRI ${ }^{60} \mathrm{Co}$ facility [25]. Mice exposed to this level of total body irradiation display a rapid decline of all mature blood cell types, with a corresponding loss of hematopoietic progenitors in the bone marrow compartment $[3,6]$. Protein carbonylation is a key marker for protein oxidation, including in response to radiation exposure $[15,26,27]$. We therefore investigated protein carbonylation in the bone marrow at $24 \mathrm{~h}$ postirradiation (Figure 1). Two dimensional gel electrophoresis and Oxyblot analysis detected 13 carbonylated proteins in sham-irradiated and irradiated bone marrow samples. Twelve of these features were present in sham-irradiated bone marrow (spots 1-12) whereas feature 13 was only observed in the irradiated marrow sample. Interestingly, as compared to control, radiation exposure dramatically altered the pattern of protein carbonylation. The carbonylation status of 5 proteins was increased by radiation (spots 6, 9, 10, 12, and 13). Interestingly, the degree of carbonylation of 5 others was decreased following radiation exposure (spots $1,2,3,4$, and 5). The carbonylation levels of 3 proteins were relatively unchanged by radiation (spots $7,8,11$ ). This indicates that radiation-induced carbonylation occurs in an order process, differentially effecting specific proteins in bone marrow.

Figure 1. Two dimensional gel electrophoresis and Oxtblot analysis of sham-irradiated and irradiated bone marrow proteins. C57BL/6 mice were either sham irradiated (control) or exposed to 7.5 Gy TBI. Bone marrow cell lysates were obtained $24 \mathrm{~h}$ postirradiation, and protein lysates were combined from 3 mice for one gel. Upper panels: Oxyblot. Lower panels: Coomassie stained gels. Proteins detected by Oxyblot are indicated with numbered arrows. Immunoblots and gels are representative.
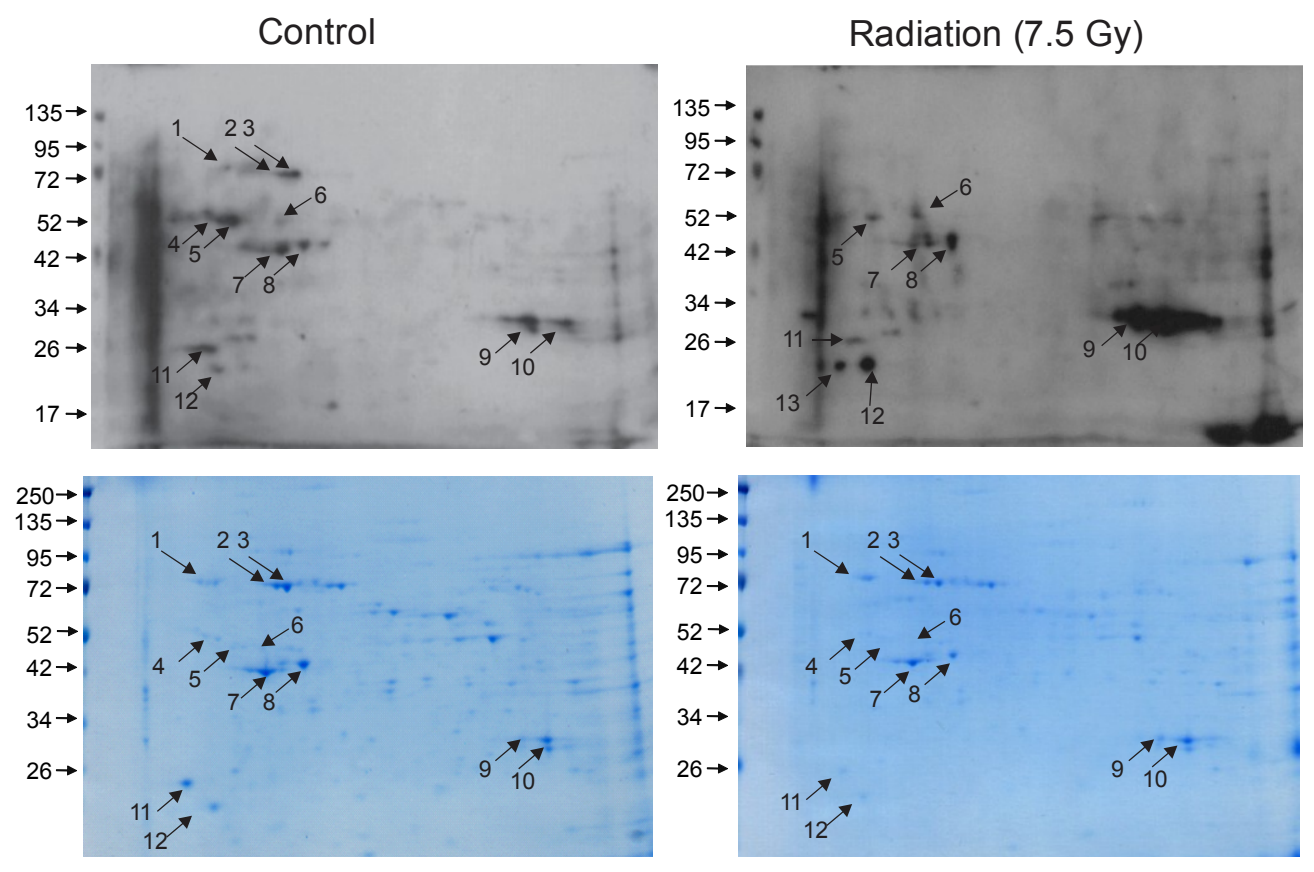


\subsection{Identification of Carbonylated Proteins from Control and Irradiated Bone Marrow Tissue}

Carbonylated proteins were excised from corresponding Coomassie-stained gels and subjected to peptide mass fingerprinting for protein identification. Definitive identifications were obtained only seven of the thirteen proteins, listed in Table 1.

Table 1. Carbonylated proteins were identified by peptide mass finger printing. Numbers correspond to spot numbers identified in 2-D gels of control and irradiated bone marrow proteins (Figure 1). Symbols,,,-++++++ indicate relative levels of protein carbonylation in control vs. total body irradiation (7.5 Gy).

\begin{tabular}{cccccc}
\hline $\begin{array}{c}\text { Spot } \\
\text { No. }\end{array}$ & Protein ID & \# Peptides & \% Coverage & Control & Radiation \\
\hline 1 & 78 kDa glucose-regulated protein (GRP78) & 22 & 37.5 & + & - \\
2 & Heat shock cognate 71 kDa protein (HSC71) & 19 & 38.9 & ++ & - \\
3 & Heat shock cognate 71 kDa protein (HSC71) & 29 & 52.5 & ++ & - \\
6 & Chitinase-like protein 3 (CHI3L1 or YKL-40) & 19 & 53.8 & + & ++ \\
7 & Actin, cytoplasmic & 15 & 49.6 & + & + \\
8 & Actin, cytoplasmic & 10 & 29.3 & + & + \\
10 & Carbonic anhydrase 2 (CAII) & 12 & 67.7 & + & +++ \\
\hline
\end{tabular}

The proteins identified here function as either enzymes or in protein-protein interactions. Protein carbonylation proteomics by others have been performed in studies of chemical- and radiation-induced oxidative injury as well as various disease states associated with oxidative stress, such as diabetes mellitus, neurodegenerative diseases, inflammatory diseases, and cancer [12,28-31]. Our current findings correlate with other investigations where enzymes were demonstrated to compose a large number of the identified carbonylated proteins.

Chitinase-3-like 1 (CHI3L1/YKL-40) is a glycoprotein upregulated in response to immune system activation and is a blood biomarker for inflammation [32,33]. The function of CHI3L1 is controversial. In some cases, CHI3L appears inhibit inflammation, including suppression of the expression and secretion of interleukins [33]. However, other studies have shown the binding of CHI3L1 to interleukin receptors to induce macrophage activation [34]. Interestingly, chitinase was also shown to be upregulated in patients with asthma and other chronic inflammatory and remodeling diseases [35], but the carbonylation of CHI3L1 has not been previously demonstrated.

Carbonic anhydrase, a regulator of acid-base homeostasis, like actin, was previously shown to be carbonylated in skeletal muscle following high levels of ROS production as well as in some animal models of muscle dysfunction and in patients with chronic obstructive pulmonary disease [36,37].

The $78 \mathrm{kDa}$ glucose-regulated protein (GRP78) is an ER chaperone that has been suggested to protect cells against damage by ROS; upregulation of GRP78 is associated with ER stress in cultured cells and in vivo in the brain, liver, and heart [38-41]. The heat shock cognate $71 \mathrm{kDa}$ protein (HSC71) is also a chaperone, also demonstrated to be upregulated in response to redox stress [42] and HSC71 was demonstrated to contain increased carbonyl levels in Alzheimer's disease [43]. HSC71 contains a reversibly oxidized cysteine that is responsive to ROS levels inside cells, but function of oxidation of the protein and the site of carbonylation relative to the oxidize cysteine are not yet known [44]. Both 
GFP78 and HSC71 were demonstrated to be oxidized in response to arsenic trioxide treatment of HTLV-1-infected HeLa cells in culture [45].

Finally, actin, a ubiquitous cellular protein required for normal biological function in all cell types, was previously shown to be carbonylated primary astrocytes following 1,3-dinitrobenzene exposure and in HL-60 human leukemia cells following peroxide-induced oxidative stress [19,29]. A recent investigation of oxidation and reduction thiols in cellular proteins found that actins contain a redoxsensitive cysteine, but it the structural site of the carbonylation is not yet known [44].

\section{Conclusions}

The findings presented here show that ionizing radiation differentially affects the carbonylation state of specific bone marrow proteins. The mechanism by which radiation causes a decrease in carbonylation of some proteins, but not others, remains unknown. Although carbonylation is largely considered to be an irreversible event, requiring protein degradation for its elimination, some recent reports suggest that carbonylated proteins may undergo further modification, suggesting a specific function for carbonylation $[21,46]$. The pattern of response that we observe suggests that radiationinduced carbonylation occurs is an ordered process, differentially effecting specific proteins and sparring others. The distinctive pattern of protein carbonylation in bone marrow may constitute a biosignature for radiation injury and suggests a causative mechanism for radiation-induced disruptions in hematopoiesis. While the number of proteins identified here is too small to assemble biochemical pathways underlying bone marrow pathology, the findings constitute a first step towards a more comprehensive understanding of how radiation can affect the functions of bone marrow.

\section{Acknowledgments}

This work was supported by Defense Medical Research and Development Program (DMRDP) Grant D61_I_10_J7_62 and by the USUHS/Henry M. Jackson Foundation for Military Medicine Joint Office of Technology Transfer (JOTT) award KL75RC to RMD and GPM. Some of the authors are employees of the U.S. Government. This work was prepared as part of their official duties. Title 17 U.S.C. $\$ 105$ provides that "Copyright protection under this title is not available for any work of the United States Government”. Title 17 U.S.C \$101 defined a U.S. Government work as a work prepared by a military service member or employees of the U.S. Government as part of that person's official duties. The views in this article are those of the authors and do not necessarily reflect the views, official policy or position of the Uniformed Services University of the Health Sciences, the Armed Forces Radiobiology Research Institute, Department of the Navy, Department of Defense or the U.S. Federal Government.

\section{Author Contributions}

Participated in research design: Kim, Barshishat-Kupper, McCart, Mueller and Day. Conducted experiments: Kim, Barshishat-Kupper, McCart. Performed data analysis: Kim, Barshishat-Kupper, McCart, Mueller and Day. Wrote or contributed to the writing of the manuscript: Kim, Barshishat-Kupper, McCart, Mueller and Day. 


\section{Conflicts of Interest}

The authors declare no conflict of interest.

\section{References}

1. Meder, J.; Michalowski, A. Changes in cellularity and/or weight of mouse hemopoietic Tissues as a measure of acute radiation effects. Arch. Immunol. Ther. Exp. (Warsz) 1980, 28, 9-18.

2. Mauch, P.; Constine, L.; Greenberger, J.; Knospe, W.; Sullivan, J.; Liesveld, J.L.; Deeg, H.J. Hematopoietic stem cell compartment: Acute and late effects of radiation therapy and chemotherapy. Int. J. Radiat. Oncol. Biol. Phys. 1995, 31, 1319-1339.

3. Davis, T.A.; Landauer, M.R.; Mog, S.R.; Barshishat-Kupper, M.; Zins, S.R.; Amare, M.F.; Day, R.M. Timing of captopril administration determines radiation protection or radiation sensitization in a murine model of total body irradiation. Exp. Hematol. 2010, 38, 270-281.

4. Passegue, E.; Wagers, A.J.; Giuriato, S.; Anderson, W.C.; Weissman, I.L. Global analysis of proliferation and cell cycle gene expression in the regulation of hematopoietic stem and progenitor cell fates. J. Exp. Med. 2005, 202, 1599-1611.

5. Cheng, T.; Rodrigues, N.; Shen, H.; Yang, Y.; Dombkowski, D.; Sykes, M.; Scadden, D.T. Hematopoietic stem cell quiescence maintained by p21cip1/wafl. Science 2000, 287, 1804-1808.

6. Davis, T.A.; Mungunsukh, O.; Zins, S.; Day, R.M.; Landauer, M.R. Genistein induces radioprotection by hematopoietic stem cell quiescence. Int. J. Radiat. Biol. 2008, 84, 713-726.

7. Wang, Y.; Schulte, B.A.; LaRue, A.C.; Ogawa, M.; Zhou, D. Total body irradiation selectively induces murine hematopoietic stem cell senescence. Blood 2006, 107, 358-366.

8. Hirabayashi, Y. Radiation-induced, cell cycle-related gene expression in aging hematopoietic stem cells: Enigma of their recovery. Ann. N. Y. Acad. Sci. 2014, 1310, 69-73.

9. Hirabayashi, Y.; Inoue, T. Prediction of epigenetic and stochastic gene expression profiles of late effects after radiation exposure. In Toxicology and Epigenetics; Sahu, S.C., Ed.; John Wiley \& Sons, Ltd.: Hoboken, NJ, USA, 2012; pp. 475-510.

10. Zhang, J.; Yang, Y.; Wang, Y.; Wang, Z.; Yin, M.; Shen, X. Identification of Hub genes related to the recovery phase of irradiation injury by microarray and integrated gene network analysis. PLoS One 2011, 6, e24680.

11. Sanzari, J.K.; Wambi, C.; Lewis-Wambi, J.S.; Kennedy, A.R. Antioxidant dietary supplementation in mice exposed to proton radiation attenuates expression of programmed cell death-associated genes. Radiat. Res. 2011, 175, 650-656.

12. Chen, C.; Lorimore, S.A.; Evans, C.A.; Whetton, A.D.; Wright, E.G. A proteomic analysis of murine bone marrow and its response to ionizing radiation. Proteomics 2005, 5, 4254-4263.

13. Wang, Y.; Liu, L.; Pazhanisamy, S.K.; Li, H.; Meng, A.; Zhou, D. Total body irradiation causes residual bone marrow injury by induction of persistent oxidative stress in murine hematopoietic stem cells. Free Radic. Biol. Med. 2010, 48, 348-356.

14. Zhang, H.; Wang, Y.A.; Meng, A.; Yan, H.; Wang, X.; Niu, J.; Li, J.; Wang, H. Inhibiting TGFbeta1 has a protective effect on mouse bone marrow suppression following ionizing radiation sxposure in vitro. J. Radiat. Res. 2013, 54, 630-636. 
15. Daly, M.J.; Gaidamakova, E.K.; Matrosova, V.Y.; Vasilenko, A.; Zhai, M.; Leapman, R.D.; Lai, B.; Ravel, B.; Li, S.M.; Kemner, K.M.; et al. Protein oxidation implicated as the primary determinant of bacterial radioresistance. PLoS Biol. 2007, 5, e92.

16. Du, J.; Gebicki, J.M. Proteins are major initial cell rargets of hydroxyl free radicals. Int. J. Biochem. Cell Biol. 2004, 36, 2334-2343.

17. Panganiban, R.A.; Mungunsukh, O.; Day, R.M. X-irradiation induces ER stress, apoptosis, and senescence in pulmonary artery endothelial cells. Int. J. Radiat. Biol. 2012, 89, 656-667.

18. McPherson, C.W. Reduction of pseudomonas aeruginosa and coliform bacteria in mouse drinking water following treatment with hydrochloric acid or chlorine. Lab. Anim. Care 1963, 13, 737-744.

19. Steiner, S.R.; Philbert, M.A. Proteomic identification of carbonylated proteins in 1,3-dinitrobenzene neurotoxicity. Neurotoxicology 2011, 32, 362-373.

20. Image J Software. Available online: http://rsbweb.nih.gov/ij/ (accessed on 18 August 2012).

21. Wong, C.M.; Cheema, A.K.; Zhang, L.; Suzuki, Y.J. Protein carbonylation as a novel mechanism in redox signaling. Circ. Res. 2008, 102, 310-318.

22. Muth, E.; Driscoll, W.J.; Smalstig, A.; Goping, G.; Mueller, G.P. Proteomic analysis of rat atrial secretory granules: A platform for testable hypotheses. Biochim. Biophys. Acta 1999, 71, 2871-2882.

23. Proteinprospector Ms-Fit Search Engine. Available online: http://prospector.ucsf.edu/prospector/ mshome.htm (accessed on 6 October 2013).

24. Clauser, K.R.; Baker, P.; Burlingame, A.L. Role of accurate mass measurement $(+/-10 \mathrm{ppm})$ in protein identification strategies employing MS or MS/MS and database searching. Anal. Chem. 1999, 71, 2871-2882.

25. Day, R.; Barshishat-Kupper, M.; Mog, S.R.; McCart, E.; Prasanna, P.; Davis, T.; Landauer, M. Genistein protects against biomarkers of delayed lung sequelae in nice surviving high dose total body irradiation. J. Radiat. Res. 2008, 49, 361-372.

26. Farber, J.M.; Levine, R.L. Sequence of a peptide susceptible to mixed-function oxidation. Probable cation binding site in glutamine synthetase. J. Biol. Chem. 1986, 261, 4574-4578.

27. Stadtman, E.R.; Levine, R.L. Protein Oxidation. Ann. N. Y. Acad. Sci. 2000, 899, 191-208.

28. Madian, A.G.; Myracle, A.D.; Diaz-Maldonado, N.; Rochelle, N.S.; Janle, E.M.; Regnier, F.E. Differential carbonylation of proteins as a function of in vivo oxidative stress. J. Proteome Res. 2011, 10, 3959-3972.

29. England, K.; Cotter, T. Identification of carbonylated proteins by MALDI-TOF mass spectroscopy reveals susceptibility of ER. Biochem. Biophys. Res. Commun. 2004, 320, 123-130.

30. Mori, H.; Oikawa, M.; Tamagami, T.; Kumaki, H.; Nakaune, R.; Amano, J.; Akinaga, Y.; Fukui, K.; Abe, K.; Urano, S. Oxidized proteins in astrocytes generated in a hyperbaric atmosphere induce neuronal apoptosis. J. Alzheimers Dis. 2007, 11, 165-174.

31. Linares, M.; Marín-Garcíía, P.; Méndez, D.; Puyet, A.; Diez, A.; Bautista, J.M. Proteomic approaches to identifying carbonylated proteins in brain tissue. J. Proteome Res. 2011, 10, 1719-1727.

32. Sánchez, O.; Rodriguez-Sureda, V.; Dománguez, C.; Ferníndez-Figueras, T.; Vilches, A.; Llurba, E.; Alijotas-Reig, J. Study of biomaterial-induced macrophage activation, cell-mediated immune response and molecular oxidative damage in patients with dermal bioimplants. Immunobiology 2012, 217, 44-53. 
33. Görgens, S.W.; Eckardt, K.; Elsen, M.; Tennagels, N.; Eckel, J. Chitinase-3-like protein 1 protects skeletal muscle from TNFalpha-induced inflammation and insulin resistance. Biochem. J. 2014, 459, 479-488.

34. He, C.H.; Lee, C.G.; Dela Cruz, C.S.; Lee, C.M.; Zhou, Y.; Ahangari, F.; Ma, B.; Herzog, E.L.; Rosenberg, S.A.; Li, Y.; et al. Chitinase 3-like 1 regulates cellular and tissue responses via IL-13 receptor alpha2. Cell Rep. 2013, 4, 830-841.

35. Lee, C.G.; Da Silva, C.A.; Dela Cruz, C.S.; Ahangari, F.; Bing, M.; Kang, M.-J.; He, C.-H.; Takyar, S.; Elias, J.A. Role of Chitin and chitinase/chitinase-like proteins in inflammation, tissue remodeling, and injury. Ann. Rev. Physiol. 2011, 73, 479-501.

36. Fermoselle, C.; Rabinovich, R.; Ausin, P.; Puig-Vilanova, E.; Coronell, C.; Sanchez, F.; Roca, J.; Gea, J.; Barreiro, E. Does oxidative stress modulate limb muscle atrophy in severe COPD patients? Eur. Respir. J. 2012, 40, 851-862.

37. Barreiro, E.; Hussain, S.N. Protein carbonylation in skeletal muscles: Impact on function. Antioxid. Redox Signal. 2010, 12, 417-429.

38. Suyama, K.; Watanabe, M.; Sakabe, K.; Otomo, A.; Okada, Y.; Terayama, H.; Imai, T.; Mochida, J. Grp78 suppresses lipid peroxidation and promotes cellular antioxidant levels in glial cells following hydrogen peroxide exposure. PLoS One 2014, 9, e86951.

39. Chao, Y.M.; Lai, M.D.; Chan, J.Y. Redox-sensitive endoplasmic reticulum stress and autophagy at rostral ventrolateral medulla contribute to hypertension in spontaneously hypertensive rats. Hypertension 2013, 61, 1270-1280.

40. Mozzini, C.; Fratta Pasini, A.; Garbin, U.; Stranieri, C.; Pasini, A.; Vallerio, P.; Cominacini, L. Increased endoplasmic reticulum stress and $\mathrm{Nrf} 2$ repression in peripheral blood mononuclear cells of patients with stable coronary artery disease. Free Radic. Biol. Med. 2014, 68, 178-185.

41. Banerjee, A.; Abdelmegeed, M.A.; Jang, S.; Song, B.J. Zidovudine (AZT) and hepatic lipid accumulation: Implication of inflammation, oxidative and endoplasmic reticulum stress mediators. PLoS One 2013, 8, e76850.

42. Ding, Y.; Li, X.R.; Yang, K.Y.; Huang, L.H.; Hu, G.; Gao, K. Proteomics analysis of gastric epithelial Ags cells infected with Epstein-Barr virus. Asian Pac. J. Cancer Prev. 2013, 14, 367-372.

43. Castegna, A.; Aksenov, M.; Aksenova, M.; Thongboonkerd, V.; Klein, J.B.; Pierce, W.M.; Booze, R.; Markesbery, W.R.; Butterfield, D.A. Proteomic identification of sxidatively modified proteins in Alzheimer's Disease brain. Part I: Creatine kinase Bb, glutamine synthase, and ubiquitin carboxy-terminal hydrolase L-1. Free Radic. Biol. Med. 2002, 33, 562-571.

44. Fuentes-Almagro, C.A.; Prieto-Alamo, M.J.; Pueyo, C.; Jurado, J. Identification of proteins containing redox-sensitive thiols after Prdx1, Prdx3 and Gclc silencing and/or glucose oxidase treatment in Hepa 1-6 Cells. J. Proteomics 2012, 77, 262-279.

45. Nabeshi, H.; Yoshikawa, T.; Kamada, H.; Shibata, H.; Sugita, T.; Abe, Y.; Nagano, K.; Nomura, T.; Minowa, K.; Tsunoda, S.; Tsutsumi, Y. Arsenic trioxide induces down-regulation of Gp46 via protein oxidation: Proteomics analysis of oxidative modified proteins in As2o3-treated HTLV-1-infected cells. Pharmazie 2010, 65, 702-707. 
46. Wong, C.M.; Marcocci, L.; Liu, L.; Suzuki, Y.J. Cell Signaling by Protein Carbonylation and Decarbonylation. Antioxid. Redox Signal. 2010, 12, 393-404.

(C) 2014 by the authors; licensee MDPI, Basel, Switzerland. This article is an open access article distributed under the terms and conditions of the Creative Commons Attribution license (http://creativecommons.org/licenses/by/3.0/). 